\title{
Trends in Misuse of Agricultural Lands in Erzurum Plain of Eastern Turkey
}

\author{
Müdahir Özgül ${ }^{1}$, Emre Çomaklı ${ }^{*}$ \\ ${ }^{1}$ Ataturk Univ. Fac. of Agric. Dept. of Soil Sci.\& Plant Nutr. 25240 Erzurum, Turkey (ORCID:0000-0002-5855-0086), mozgul@atauni.edu.tr \\ ${ }^{2 *}$ Ataturk Univ. Environmental Problems Res. and App. Center, 25240, Erzurum, Turkey (ORCID:0000-0001-8477-7076), emrecomakli@atauni.edu.tr
}

(1st International Conference on Applied Engineering and Natural Sciences ICAENS 2021, November 1-3, 2021)

(DOI: 10.31590/ejosat.1008168)

\begin{abstract}
ATIF/REFERENCE: Özgül, M., Çomakl1, E. (2021). Trends in Misuse of Agricultural Lands in Erzurum Plain of Eastern
\end{abstract} Turkey. European Journal of Science and Technology, (28), 500-505.

\begin{abstract}
Natural resource conservation, sustainable land management, adaptation to climate change, and increasing ecosystem resistance are the main research issues in the last decades. The objective of this study was to assess the quantity and the trends in misuse of agricultural lands within the 8-year period (2010-2018) in Erzurum, the 4th largest province of Turkey. A total of 488454 hectares of agricultural land, of which 143842 hectares are "the most suitable for cultivated agriculture-S1" and 344612 hectares "suitable for cultivated agriculture-S2", were defined for Erzurum province. These two classes of agricultural lands occupy $19.6 \%$ of the province's total land assets. The amount of land occupied in Erzurum plain in the period of 2000-2018 is 13161 decares. Approximately $40 \%$ of the occupied land (3 833 decares) are in I and II. Class lands. Some of the physical and chemical properties of the soil change depending on the landuse changes in productive agricultural lands for various reasons. These changes also affect the amount of carbon capture in soils, making soils vulnerable to the effects of climate changes. In this context, it is necessary to develop sustainable agricultural land use policies. Legal and institutional arrangements to be made should primarily aim to protect agricultural lands and increase their productivity.
\end{abstract}

Keywords: Erzurum plain, misuse of agricultural lands, land capability classification

\section{Erzurum Ovasındaki Tarım Arazilerinin Amaç Dışı Kullanımındaki Eğilimler}

$\ddot{O} \mathbf{z}$

Doğal kaynakların korunması, sürdürülebilir arazi yönetimi, iklim değişikliğine uyum ve ekosistem direncinin artırılması son on yılın temel araştırma konularıdır. Bu çalışmanın amacı, Türkiye'nin 4. büyük ili olan Erzurum'daki tarım arazilerinin 8 yıllık dönem içerisindeki (2010-2018) miktarlarını ve amaç dışı kullanım eğilimlerini değerlendirmektir. Erzurum ili için 143.842 hektarı "ekili tarıma en uygun-S1" ve 344.612 hektarı "ekili tarıma uygun-S2" olmak üzere toplam 488454 hektar tarım arazisi tanımlanmıştır. Tanımlanan bu iki tarım arazisi sınıfı, ilin toplam arazi varlı̆̆ının \%19,6'sını oluşturmaktadır. Erzurum ovasında 2000-2018 döneminde işgal edilen arazi miktarı 13161 dekardır. Amaç dışı kullanılan arazilerin yaklaşı \%40'ı (3 833 dekar) I ve II. sınıf tarım arazileridir. Verimli tarım arazilerinde çeşitli nedenlerle arazi kullanım değişikliklerine bağlı olarak toprağın bazı fiziksel ve kimyasal özellikleri değişmektedir. Aynı zamanda bu değişiklikler toprakların karbon tutma miktarını da etkileyerek, toprakları iklim değişikliklerinin olumsuz etkilerine karşı savunmasız hale getirmektedir. Bu bağlamda sürdürülebilir tarımsal arazi kullanım politikalarının geliştirilmesi gerekmektedir. Yapılacak yasal ve kurumsal düzenlemeler, öncelikle tarım arazilerinin korunmasını ve verimliliklerinin artırılmasını amaçlamalıdır.

Anahtar Kelimeler: Erzurum ovası, tarım arazilerinin amaç dışı kullanımı, arazi kullanım kabiliyet sınıflandırması. 


\section{Introduction}

Global climate change, population growth, urbanization, and industrialization cause serious land degradation in many parts of the world. This situation not only restricts healthy food production but also causes serious social and economic problems [1]. In the United Nations Convention to Combat Desertification (UNCCD) 2018-2030 Strategic Framework document, it was stated that "desertification, land degradation, and drought lead to economic, social and environmental problems such as poverty, health problems, food safety risk, biodiversity loss, water scarcity, the decline in resistance to climate change and forced migration". It was also stated that these problems cause serious difficulties for the sustainable development of all countries, especially in the affected countries [2]. Increased competition for the use of land resources will lead to increased social and political instability [3]. Effective management by addressing all aspects of land degradation is critical to minimizing the negative effects of climate change and protecting biological diversity, as well as ensuring food security and sustainability of livelihoods. At the same time, land degradation neutrality (LDN) has been adopted as a target for Sustainable Development Goal 15, and achieving LDN is the primary goal of the UNCCD [4]. Turkey is one of the high-risk countries facing serious land degradation and desertification issues because of climate change as well as the increasing pressure on natural resources due to land demand [5]. However, with the misuse and inappropriate agricultural practices made within the scope of land planning and management, wellqualified lands that are the guarantee of our future are constantly shrinking. Lands of Turkey suffer severely from degradation processes specifically by soil erosion, compaction, acidification, salinization, alkalization, organic matter loss, fertility decline, and contamination. Moreover, surface sealing recently became the most threatened degradation factor because of increasing pressures by industrial developments, population growth, and urbanization [5]. Land capability class is a rational evaluation that reveals what the land should be used for. Of course, not all lands serve all kinds of purposes, but as long as they are used within their ability and capacity, the highest value can be produced from that land. The use of agricultural lands for activities other than agriculture results in loss of biological productivity over time. This is particularly important for the regions with limited agricultural land potential. Although Erzurum consists of about $1 / 30$ of Turkey's lands, the amounts of suitable lands for agriculture are limited. As in all over the country, misuse and mismanagement of lands are also common in the Erzurum provincial scale, which results in the loss of agricultural lands in a way that cannot be recycled. Therefore, it has critical importance in terms of land use planning and land management.

A few important studies have been carried out for drawing attention to the misuse of agricultural lands in the Erzurum plain so far. Ref [6] reported that industrialization seriously threatens well-qualified agricultural lands in the Erzurum plain. Ref [7] estimated that 27150 da lands suitable for agriculture were used for non-agricultural purposes, with evaluating the plans, projects, inventory studies, and licenses from municipalities, relevant private and public institutions regarding the occupation of lands in the Erzurum plain. Ref [8] produced digital land use maps and comparative change maps for the years 2015, 2010, 2001, 1987, $1960,1958,1953,1947$ in light of the information obtained from the satellite images, aerial photographs, and topography maps of the Erzurum plain. It was reported that significant changes in all land use types from the settlement areas to the agricultural areas and from the wetlands to the transportation networks in the Erzurum Plain were obtained within the 68 -year period.

GIS techniques, which use different criteria and weights, are widely used in determining suitable areas for the growth of urban areas and monitoring their effects on the ecosystem [9], [10]. AHP, which is a multi-criteria decision analysis approach in determining the effects of land use changes; is one of the effective techniques used by planners, integrated with GIS tools. The fact that it is an approach that can be used in complex decision-making processes has made the use of AHP widespread, especially in the analysis of ecosystem effects [10], [11]. But; The need for experienced experts to determine the weights of the factors used in the analysis in the implementation of the AHP model creates difficulties in practice [12].

The objective of this study was to determine the extent of occupation of well-qualified agricultural lands within the last 18 years (2000-2018) in the Erzurum plain based on the potentially suitable agricultural land map of Erzurum at provincial scale obtained by the Analytical Hierarchy Process (AHP) and GIS.

\section{Material and Method}

Erzurum consists of about $1 / 30$ of Turkey's lands. It is the largest city in Eastern Anatolia, and the 4th largest after Konya, Sivas, and Ankara in Turkey. The population of Erzurum province has been determined as 758.279 according to the records of 2020 . The economy of Erzurum province is generally based on agriculture, livestock, and the service sector. The importance of Palandöken Mountain for winter tourism has enabled the tourism sector to progress especially in recent years. It is the most important province of the Eastern Anatolia Region with its high altitude and rugged topography, depression areas, wide valley bases, flat plains. Its total surface area is $25.066 \mathrm{~km}^{2}$ and its average altitude from sea level is about $1950 \mathrm{~m}$. The annual average rainfall is $432.2 \mathrm{~mm}$ and the annual average air temperature is $6 \mathrm{C}^{\circ}[13]$. The location map of the research area is presented in Figure 1. 


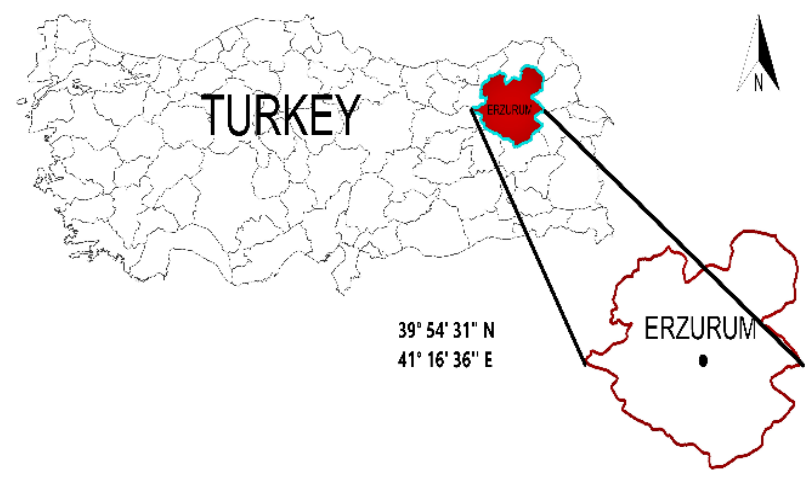

Figure. 1. Location map of Erzurum province

A significant portion of the provincial land assets is mountains (63.7\%); Rize Mountains, North Anatolian Mountains, and Karasu-Aras mountains. Plains; Erzurum plain, Pasinler plain, and Hınıs plain consists of about $4 \%$ of the total land assets of the province. Erzurum and Pasinler plains are separated from each other by the Deveboynu strait at an altitude of $2030 \mathrm{~m}$. The altitude of the lowest point of the Erzurum plain is $1850 \mathrm{~m}$. and the altitude of the lowest point of the Pasinler plain is approximately $1650 \mathrm{~m}$. Terrestrial climate characteristics are dominant in the vast majority of the provincial land. The dominant natural vegetation in the provincial land is steppe formation. While the altitude from sea level varies between 800 and $3800 \mathrm{~m}$ in Erzurum, the average altitude of Erzurum plain is $1950 \mathrm{~m}$ (Figure 2). The slope change in the provincial scale is quite high. Especially in the northern part of the province, the slope degree is over $45 \%$ (Figure 3). On the other hand, the average slope in Erzurum plain is $3 \%$. In terms of slope, only $26.5 \%$ (656782.6 ha) of the province has less than $12 \%$ slope degree that is envisaged as an agricultural limit for cultivation.

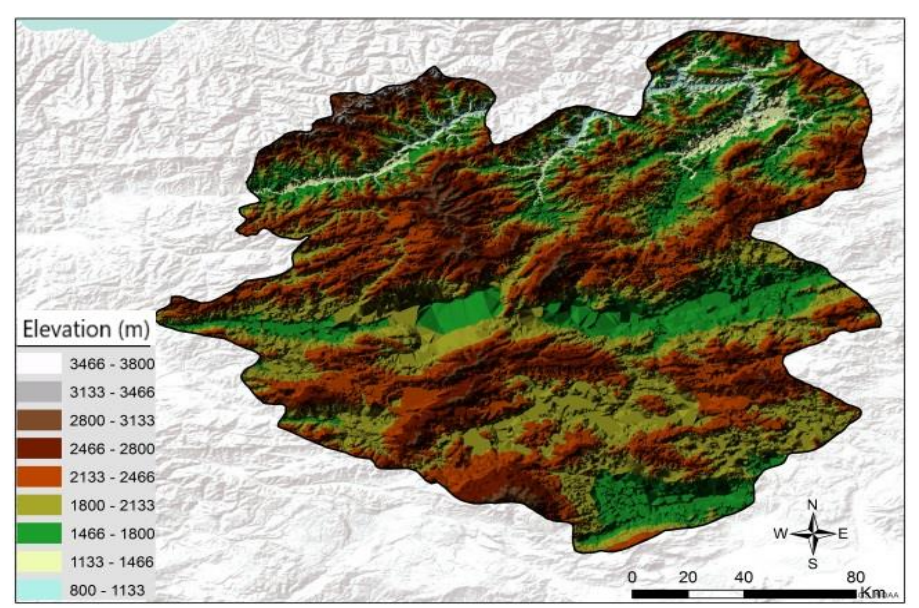

Figure. 2. Elevation map of Erzurum province

\section{Results and Discussion}

Land use/land cover classification of Erzurum Province made according to CORINE-2012 can be seen in Table 1 and Figure 4. Approximately $56 \%$ of the province consists of pasturelands, with about $27 \%$ dry agriculture and natural vegetation together with agricultural fields.

The proportional distributions of the potentially cultivated agricultural areas of Erzurum obtained by using the HP approach are given in Table 2 and Figure 5. It was determined that $19.64 \%$ of the provincial land assets are suitable for cultivated agriculture

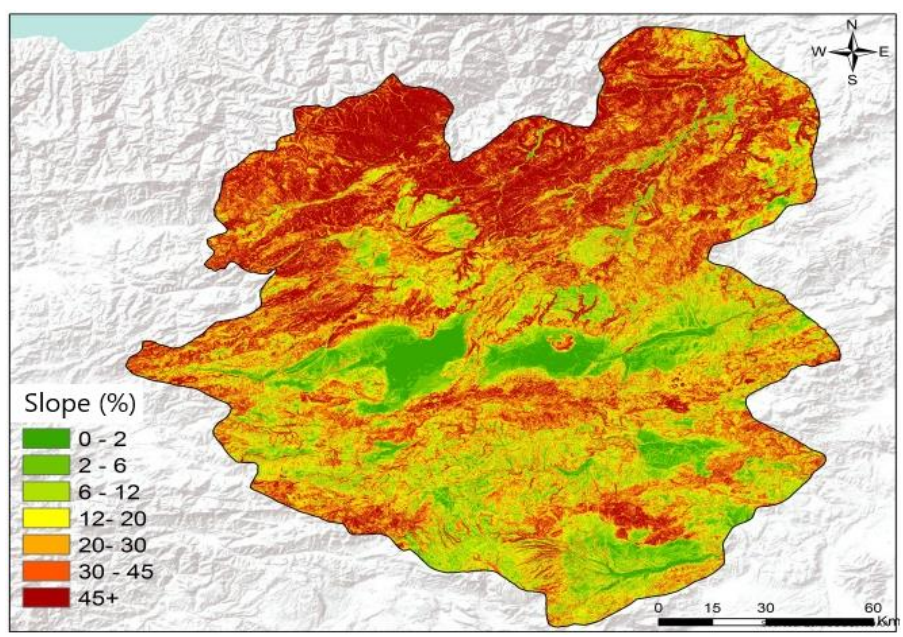

Figure. 3. Slope map of Erzurum province

In this study, the AHP (Analytical Hierarchal Process) methodology was used in determining the potentially cultivated agricultural areas of Erzurum. Also, a multi-criteria decision analysis (MCDA) was selected and integrated with Geography Information System (GIS). It is commonly known that the evaluation of land suitability for agricultural activities is naturally regarded as a complex problem with multiple criteria. Today, besides the current techniques such as Remote Sensing (RS) and Geographic Information Systems (GIS) technologies, this challenge can be overcome by using the MCDA approaches to make rational analyses and evaluations [14], [15], [16]. In the criteria standardization and assigning criterion weights process, standardization of criteria allows the re-scaling of evaluation dimensions between 0 and 1 where 0 indicates not suitable and value 1 indicates suitable. Following the processing and preparation of data, the factors were organized in the class of fit to their weight of importance. In the AHP approach [17], the criteria are standardized, by using pairwise comparison methods. The standardization of factors or criteria brought about in ratings is based on literature and agricultural experts. In a typical AHP method, experts have to give a definite number within a 1-9 scale to the pair-wise comparison so that the priority vector can be computed. The pairwise matrix comparisons were then analyzed to produce a set of weights [18]. Land use and land cover classification of the study area were made according to CORINE2012 [19]. In addition, the amount of agricultural land occupied in the Erzurum plain in the last 18 years was determined by overcrossing the Erzurum City Planning map and the Land Use Capability Classification map of Erzurum.

at the levels of S1 (the most suitable) and S2 (suitable), whereas $49.45 \%$ of the provincial land assets are not suitable for cultivated agricultural activities.

The areas that are potentially suitable and very suitable for cultivated agriculture are distributed within the districts of Aşkale, Ilıca, Merkez, Pasinler, Köprüköy, Horasan and Tekman, Karayazı, Hınıs and Karaçoban. The areas that are presently or forever not suitable for cultivated agriculture (N1 and N2) are widely distributed in Ilıca, Pazaryolu, İspir districts, which are located in the West and North West of the province and are located in Tortum, Uzundere, Olur and Şenkaya districts. In addition, $30.91 \%$ of total lands were found to be less suitable (S3). 
Table 1. CORINE-2012 land use/land cover classification for Erzurum [19]

\begin{tabular}{|c|c|c|}
\hline Land use / Land cover & $\mathbf{x ~ 1 0 0 0 ~ h a}$ & $\mathbf{\%}$ \\
\hline Pasture & 1390.54 & 55.91 \\
\hline Dry agriculture & 379.69 & 15.27 \\
\hline $\begin{array}{c}\text { Agricultural fields with natural } \\
\text { vegetation }\end{array}$ & 269.10 & 10.82 \\
\hline Plant change areas & 133.20 & 5.36 \\
\hline Forest & 125.13 & 5.03 \\
\hline Rocky & 125.01 & 5.03 \\
\hline Mixed with fruit & 35.08 & 1.41 \\
\hline Waterway and swamp & 16.16 & 0.65 \\
\hline $\begin{array}{c}\text { Sndustrial/commercial units and } \\
\text { airport }\end{array}$ & 9.19 & 0.37 \\
\hline Total & 3.95 & 0.16 \\
\hline \multicolumn{2}{|c|}{24870.48} & 100 \\
\hline
\end{tabular}

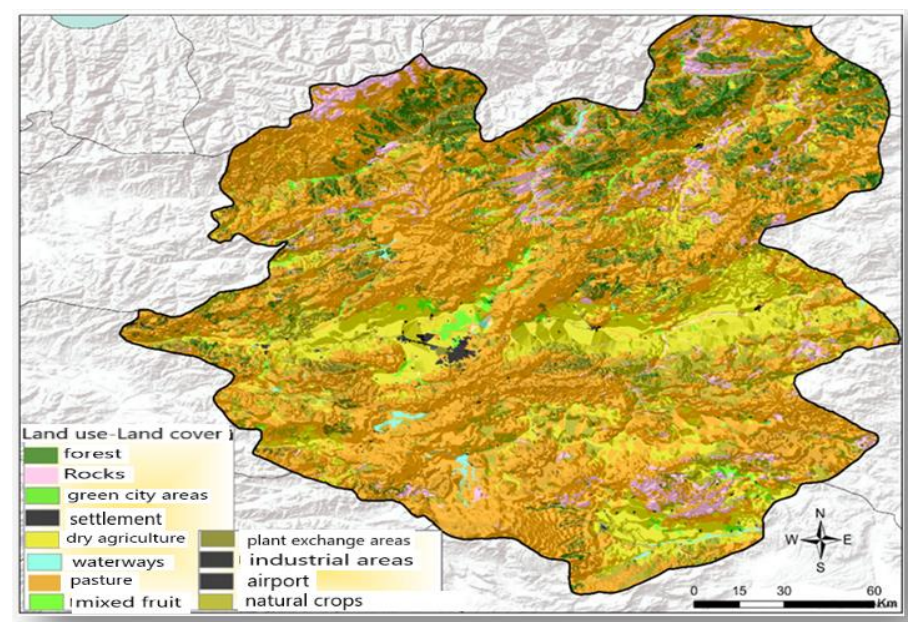

Figure. 4. CORINE-2012 land use land cover map of Erzurum province [19]

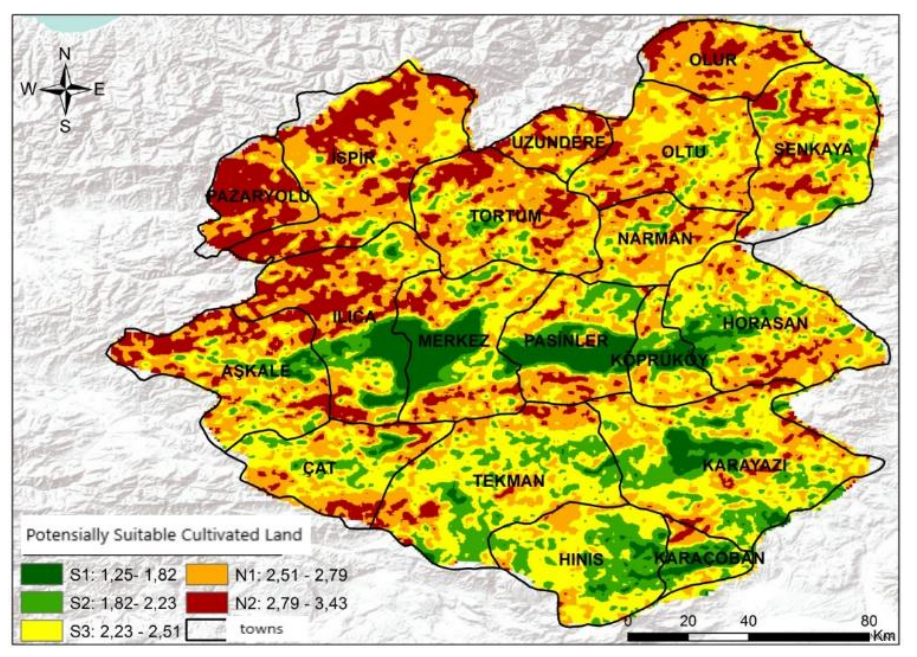

Figure. 5. Distribution map of potentially cultivated agricultural lands in Erzurum

According to the provincial inventory report Ref [20], the total of the first four classes according to the spatial and proportional distribution of the Land Use Capability classes (LCC) that make up the classes suitable for cultivated agriculture is $30.62 \%$ of the whole area. However, the first three classes are much more important for cultivated agricultural areas, which e-ISSN: 2148-2683 corresponds to about $16 \%$ of the total area. The distribution of the first three classes is similar to the distribution obtained with the model. I., II. and III. Class areas are distributed in some parts of Aşkale, Ilıca, Center, Pasinler, Köprüköy, Horasan, Karaçoban, Hınıs and Karayazı districts. Class V lands show little distribution on a provincial scale. However, VI., VII. and VIII. class lands constitute about $68 \%$ of the total area. These areas are widely distributed in the districts of the province, especially in the north, northwest and northeast sections. In the case of comparing the data obtained from the model with the classes of the LCC, the values of S1 and S2, which are suitable for cultivated agriculture, correspond to $19.6 \%$ of the province, while the value of the first three classes of the LCC is determined as $16.0 \%$. Even though these values are close to each other, the less suitable areas shown as S3 in the model are IV. compared with the class, the model evaluates approximately $31 \%$ of the area as less suitable for cultivated agriculture, while the IV. the class was determined to be about $15 \%$. In both approaches, it has been determined that more than half of the total area within the provincial boundary constitutes ineligible agricultural areas.

Table 2. Potentially cultivated agricultural areas in Erzurum

\begin{tabular}{|c|c|c|c|} 
Class & Identification & Index & Area (ha) \\
\hline S1 & $1.25-1.81$ & The most suitable & 143841.8 \\
\hline S2 & $1.82-2.38$ & Suitable & 344612.4 \\
\hline S3 & $2.39-2.50$ & Less suitable & 768783.0 \\
\hline $\mathbf{N 1}$ & $2.51-2.79$ & Presently not suitable & 834544.8 \\
\hline N2 & $2.80-3.43$ & Forever not suitable & 395262.8 \\
\hline & \multicolumn{2}{|c|}{ TOTAL } & 2487045 \\
\hline
\end{tabular}

According to the provincial inventory report Ref [20], the total of the first four classes according to the spatial and proportional distribution of the Land Use Capability classes (LCC) that make up the classes suitable for cultivated agriculture is $30.62 \%$ of the whole area. However, the first three classes are much more important for cultivated agricultural areas, which corresponds to about $16 \%$ of the total area. The distribution of the first three classes is similar to the distribution obtained with the model. I., II. and III. Class areas are distributed in some parts of Aşkale, Ilıca, Center, Pasinler, Köprüköy, Horasan, Karaçoban, Hınıs and Karayazı districts. Class V lands show little distribution on a provincial scale. However, VI., VII. and VIII. class lands constitute about $68 \%$ of the total area. These areas are widely distributed in the districts of the province, especially in the north, northwest and northeast sections. In the case of comparing the data obtained from the model with the classes of the LCC, the values of S1 and S2, which are suitable for cultivated agriculture, correspond to $19.6 \%$ of the province, while the value of the first three classes of the LCC is determined as $16.0 \%$. Although these values are close to each other, the less suitable areas shown as S3 in the model are IV. compared with the class, the model evaluates approximately $31 \%$ of the area as less suitable for cultivated agriculture, while the IV. the class was determined to be about $15 \%$. In both approaches, it has been determined that more than half of the total area within the provincial boundary constitutes ineligible agricultural areas. 
According to the land use classification standards of the Erzurum plateau, the length of which is $25-26 \mathrm{~km}$ and the width is $14-28 \mathrm{~km}$, the land asset is $283478 \mathrm{ha}$ [21]. 15.918 hectares of total area are I.Class, 40.163 hectares are II. Class and 18,347 hectares III. Class. The amount of marginal agricultural areas (IV. Class) is 36,825 hectares.

Ref [7] reported that agricultural lands occupied by public and private sectors in Erzurum plain were 1422 da between 1970 - 80, 7237 da between 1980 - 1990 and 18.491 da between 1990 -2000 . Of the total of 1422 da lands occupied between 1970 and 1980,847 da of land was determined as I. Class and 575 da as II. Class. In the second decade covering 1980-1990, of the total of 7,357 of agricultural land occupied, 4935 da I. Class and 619 da II. Class and 1683 da III. Class. From 1990 through 2000, of the total of 18491 da used for non-agricultural purposes, 11855 da was I. Class, 4228 da II. Class and 2378 da III. Class. In other words, of the total of 27150 da occupied lands in Erzurum plain, $65 \%$ (17 $637 \mathrm{da})$ was in I. Class, 20\% (5 $422 \mathrm{da})$ in II. Class and $15 \%$ (4 $061 \mathrm{da}$ ) in III. Class.

The total amount of land occupied in Erzurum plain in the last 18 years (2000-2018) is 13161 decares (Figures 6 and 7). 3489 decares of this amount were occupied between 2000-2010 and 9672 decares between 2010 - 2018. 9651 decares of the occupied land are suitable for cultivated land (Class I-IV) and approximately $40 \%$ of the occupied land (3 833 decares) are in I and II. Class lands.

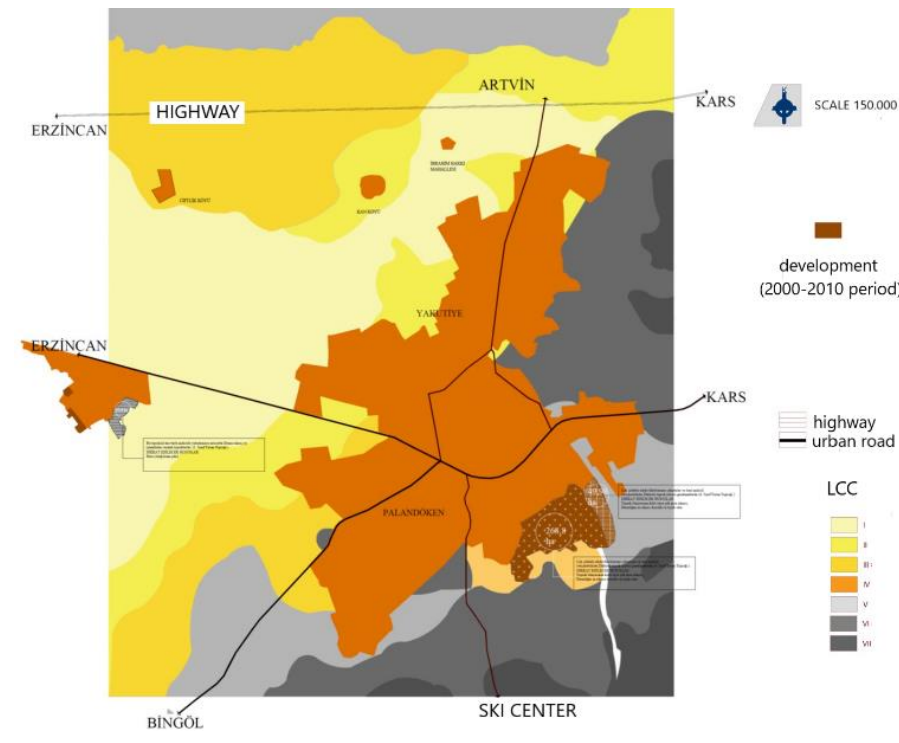

Figure 6. The lands occupied within the 2000-2010 development period in Erzurum province [22].

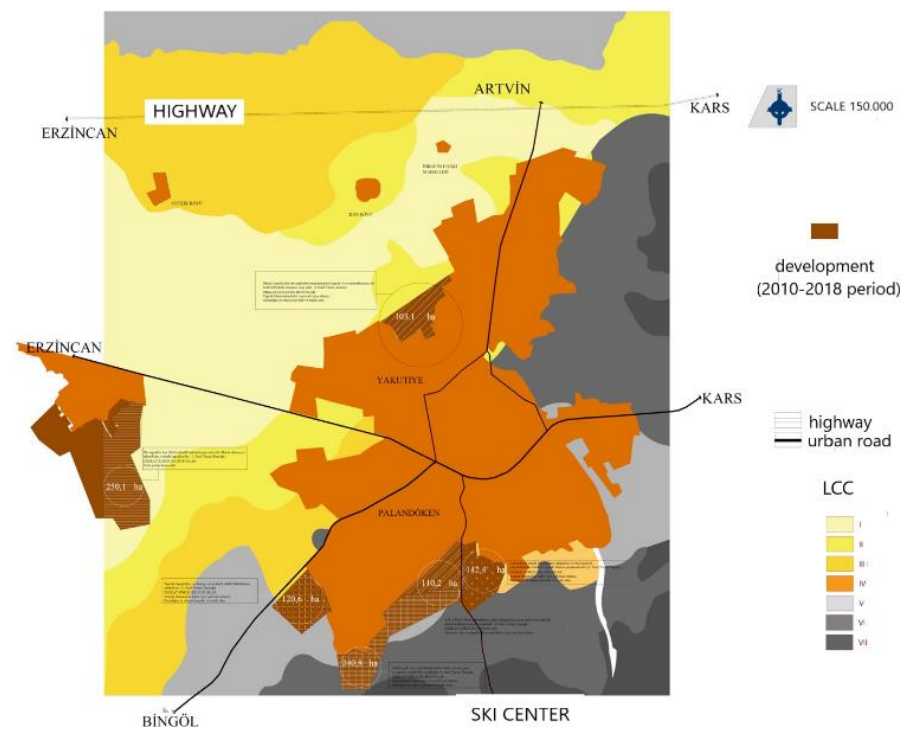

Figure. 7. The lands occupied within the 2010-2018 development period in Erzurum province [22].

The main factor of the occupation, which has been increasing since 1970 in the Erzurum plain, is the Erzurum-Erzincan highway route. The second highway passed in 1995 increased the size of the occupation on the plain geometrically. The second highway currently occupies 1810 ha agricultural land alone [7]. Occupations continue to increase with activities carried out in the context of industrialization and social services on both sides of the highways.

\section{Conclusions and Recommendations}

At the provincial scale, a total of 488454 ha agricultural land is present in Erzurum, of which 143842 hectares are "the most suitable" for cultivated agriculture (S1) and 344612 hectares "suitable" for cultivated agriculture (S2). In other words, the lands suitable for cultivation at the provincial scale constitute $19.6 \%$ of the provincial total land assets. A significant part of the lands in question is distributed in the Erzurum Center-Ilica and Pasinler plain, while the remaining part is distributed in the towns of Aşkale, Köprüköy and Horasan, Karaçoban, Hınıs and Karayazı districts. As [5] and [8] pointed out, the most important factor of the occupations that started in the Erzurum plain since the 1950s is the uncontrolled settlement and industrialization developed throughout the highways that established on over agricultural fields. It is no longer permissible to use the plain lands of the province, which are the lifeblood of agriculture, for any purpose other than agricultural purposes. With the decision of the Council of Ministers numbered 2016/9620, 2 of the 141 plains protected at the country scale are Erzurum Plain and Pasinler Plain. We believe that this development will stop the occupation of Erzurum Plain and other provincial plains with high agricultural potential.

\section{References}

[1] S. M. Metev and V. P. Veiko, Laser Assisted Microtechnology, 2nd ed., R. M. Osgood, Jr., Ed. Berlin, Germany: Springer-Verlag, 1998.

[2] UNCCD. 2017. The Convention. United Nations Convention to Combat Desertification. Official web page. http://www2.unced.int/.

[3] Decorte, F., Augustinus, C., Lind, E., \& Brown, M. Scoping and Status Study on Land and Conflict: Towards UN 
System-Wide Engagement at Scale; UN-Habitat/Global Land Tool Network (pp. 1-49). Working Paper May 2016, Report 5/2016.

[4] Cowie, A. L., Orr, B. J., Sanchez, V. M. C., Chasek, P., Crossman, N. D., Erlewein, A., ... \& Welton, S. (2018). Land in balance: The scientific conceptual framework for Land Degradation Neutrality. Environmental Science \& Policy, 79.2535

[5] Oztas, 2019. FOR A LIVABLE FUTURE; Work and Fight for a Land Degradation Neutral World. International Congress on Engineering and Life Science. April 11-14, 2019. Kastamonu Turkey.

[6] Sevim, Z., 1980. Erzurum'da Amaç Dişı Kullanılan Tarımsal Alanlar. Bölgesel Çevre Sorunları Simpozyumu. Tebliğ Özetleri. Atatürk Üni. Çevre Sonları Araştırma Enstitüsü. Erzurum.

[7] Ozbek, A.K, Oztas, T, 2004. Tarım Arazilerinin Amaç Dışı Kullanımı; Erzurum Örneği. Ekoloji Dergisi, 13(52),1-6.

[8] Sevindi, C. 2018. Erzurum Ovası'nda 1947-2015 Y1lları Arasında Arazi Kullanımındaki Değişmeler. Atatürk Üniversitesi Sosyal Bilimler Enstitüsü Dergisi Aralık 2018 22(Özel Sayı): 2855-2873.

[9] Aburas, M. M., Abdullah, S. H., Ramli, M. F., \& Asha'ari, Z. H. (2017). Land suitability analysis of urban growth in Seremban Malaysia, using GIS based analytical hierarchy process. Procedia engineering, 198, 11281136.https://doi.org/10.1016/j.proeng.2017.07.155

[10] Mohammad, M., Sahebgharani, A., \& Malekipour, E. (2013). Urban growth simulation through cellular automata (CA), analytic hierarchy process (AHP) and GIS; case study of 8th and 12th municipal districts of Isfahan. Geographia Technica, 8(2), 57-70.

[11] Javadian, M., Shamskooshki, H., \& Momeni, M. (2011). Application of sustainable urban development in environmental suitability analysis of educational land use by using AHP and GIS in Tehran. Procedia Engineering, 21, 72-80.

[12] Bagheri, M., Sulaiman, W. N. A., \& Vaghefi, N. (2013). Application of geographic information system technique and analytical hierarchy process model for land-use suitability analysis on coastal area. Journal of coastal conservation, 17(1),

[13] TSMS. (2021). Meteorological Service Official Statistics, Weather Forecast. Retrieved from https://www.mgm.gov.tr/veridegerlendirme/il-ve-ilceler istatistik.aspx? $\mathrm{k}=\mathrm{A} \& \mathrm{~m}=\mathrm{ERZURUM}$

[14] Malczewski J. A. 1996. GIS-based approach to multiple criteria group decision making. International Journal of Geographical Information System 10 (8): 955-971.

[15] Dagistanli, C., Demirag Turan, I and Dengiz, O. 2018. Valuation of The Suitability Of Sites For Outdoor Recreation Using A Multi-Criteria Assessment Model. Arabian Journal of Geoscience, 11 (17), DOI: 10.1007/s12517-018-3856-0.

[16] Demirag Turan, I. Dengiz O, Ozkan B. 2019. Spatial assessment and mapping of soil quality index for desertification in the semi-arid terrestrial ecosystem using MCDM in interval type-2 fuzzy environment. Computers and Electronics in Agriculture. 164; 104933. https://doi.org/10.1016/j.compag.2019.104933.

[17] Saaty T.L. 2008. Decision making with the analytic hierarchy process. Int. J. Serv Sci.1:83-98
[18] Rabia A.H, Fabio T (2013) Introducing a new parametric concept for land suitability Assessment. International Journal of science and Development; Singafore, vol.4 (1), 295.DOI: 10.7763/IJESD.

[19] Dengiz, O. 2018. Erzurum ili Temel Coğrafi Özellikleri ve Potansiyel İşlemeli Tarım Alanı Varlığı Erzurum İli Arazi Kullanım Çalıştayı 26-28 Eylül Erzurum

[20] Anonymous, 2000. Erzurum İli Arazi Varlığı. KHGM.Yayınları. Rapor No: 25. Erzurum.

[21] Klingebiel, A. A., Montgomery, P.H., 1961. Land Capability Classification. Agric. Handbook 210. Soil Conserve. Service, US Gov. Printing Office, Washington, USA.

[22] Dursun, D. 2018. Kentsel Büyüme Sürecinde Arazi Yönetimi, Erzurum Örneği. Erzurum İli Arazi Kullanım Çalıştayı 26-28 Eylül Erzurum 